\title{
Vitamin, micronutrients and supplement prescribing patterns in a group of ambulatory colombian patients, 2016
}

\author{
Manuel Enrique Machado-Duque* \\ Juan Daniel Ayala-Torres** \\ Jorge Enrique Machado-Alba***
}

\begin{abstract}
"Médico. MSc en Farmacoeconomía. Grupo de Investigación en Farmacoepidemiología y Farmacovigilancia, Universidad Tecnológica de PereiraAudifarma S.A. Grupo Biomedicina, Fundación Universitaria Autónoma de las Américas. Pereira, Risaralda, Colombia.

"Médico. Grupo Biomedicina. Fundación Universitaria Autónoma de las Américas. Risaralda. Colombia.

"Médico. PhD en Farmacología. Grupo de Investigación en Farmacoepidemiología y Farmacovigilancia, Universidad Tecnológica de PereiraAudifarma S.A. Pereira, Risaralda, Colombia.

Correspondence: Jorge Enrique Machado Alba. Grupo de Investigación en Farmacoepidemiología y Farmacovigilancia. Universidad Tecnológica de Pereira-Audifarma S.A, Address: Calle 105 No. 14-140, Pereira, Risaralda, Colombia, - Zip Code: 660003. E-mail: machado@utp.edu.co. Phone: +57 3108326970
\end{abstract}

Abstract

Introduction: Vitamins and micronutrients are essential organic substances in the metabolic processes of living things, and supplementation is only recommended in conditions of nutritional deficits. Objective: To determine the prescription patterns of vitamins and supplements in a group of patients enrolled in the Colombian Health System in 2016. Methodology: This was a cross-sectional study based on a population database. Vitamin-prescribed patients of both sexes and all ages were selected for 3 consecutive months. A database was designed using the dispensing records. SPSS 23.0 was used for the univariate, bivariate and multivariate analyses. A p-value $<0.05$ was considered statistically significant. Results: In total, 9998 patients receiving vitamin supplementation were identified. A female predominance was observed $(n=8341,83.4 \%)$. The mean age was $57.7 \pm 18.7$ years. The most commonly formulated vitamins and micronutrients were vitamin D (58.0\%), calcium (55.0\%) and folic acid (25.0\%). Overall, $60.8 \%$ of patients were prescribed more than one vitamin. The most frequent multiple-nutrient association was between calcium and vitamin $D(n=5505) ; 77.3 \%$ received concurrent treatment with other medications to manage comorbidities. The probability of comedication in the multivariate analysis was higher for folic acid (OR:3.10, 95\% Cl 2.69-3.59), thiamine (OR:2.75, 95\% Cl:2.15-3.5) and calcium + vitamin D (OR:1.61, 95\% Cl: 1.42-1.82) and for those individuals older than 65 years (OR:1.24, $95 \% \mathrm{Cl}: 1.02-1.51)$. Conclusions: Vitamins are widely used in the Colombian population. The results of this study elucidate the patterns of use of these supplements and offer proposed strategies to the future and to evaluate and minimize prescriptions that are potentially inappropriate or of little therapeutic value. MÉD.UIS. 2020;33(2):41-8.

Keywords: Vitamins. Dietary supplements. Drug prescriptions. Prescription Drug Misuse. Pharmacoepidemiology. Colombia.

\section{Patrones de prescripción de vitaminas y suplementos nutricionales en un grupo de pacientes de Colombia}

Resumen

Introducción: Las vitaminas y micronutrientes son sustancias orgánicas esenciales en los procesos metabólicos de los seres vivos y solo se recomienda suplementación en condiciones con déficits nutricionales. Objetivo: Determinar los patrones de prescripción de vitaminas y suplementos en un grupo de pacientes afiliados al Sistema de Salud en Colombia, en el año 2016. Métodos: Estudio de corte transversal a partir de una base de datos poblacional. Se seleccionaron pacientes con prescripción de vitaminas por 3 meses consecutivos de ambos sexos y todas las edades. Se diseñó una base de datos con los registros de dispensación. Se usó SPSS 23.0 para análisis univariados, bivariados y multivariados. Se consideró estadísticamente significativo un valor de $p<0,05$. Resultados: Se hallaron 9998 pacientes con prescripción de suplementos vitamínicos. Se halló un predominio femenino ( $n=8341 ; 83,4 \%$ ). La edad media fue de $57,7 \pm 18,7$ años, las 
vitaminas y micronutrientes más formulados fueron: vitamina $\mathrm{D}(58,0 \%)$, calcio (55,0\%) y ácido fólico (25,0\%). El 60,8\% de pacientes tenía más de un suplemento prescrito. La asociación más frecuente fue calcio y vitamina $D(n=5505)$, y el 77,3\% recibía tratamiento simultáneo con otros medicamentos para el control de comorbilidades. La probabilidad de comedicacion en el análisis multivariado fue mayor en formulados con ácido fólico (OR:3,10; IC95\%:2,69-3,59), tiamina (OR:2,75; IC95\%:2,15-3,50), calcio+vitamina D (OR:1,61; IC95\%:1,42-1,82) y los mayores de 65 años (OR:1,24; IC95\%:1,02-1,51). Conclusiones: Las vitaminas son ampliamente usadas en la población colombiana, los hallazgos de este estudio permiten conocer un estado de los patrones de uso de estos suplementos, así como plantear estrategias para racionalizar las prescripciones potencialmente inapropiadas o de poco valor terapéutico. MÉD.UIS. 2020;33(2):41-8.

Palabras clave: Vitaminas. Suplementos dietéticos. Prescripciones de medicamentos. Prescripción inadecuada. Farmacoepidemiología. Colombia.

¿Cómo citar este artículo?: Machado-Duque ME, Ayala-Torres JD, Machado-Alba JE. Vitamin, micronutrients and supplement prescribing patterns in a group of ambulatory colombian patients, 2016. MÉD.UIS. 2020;33(2):41-8. doi: 10.18273/revmed.v33n2-2020005

\section{Introduction}

Vitamins and micronutrients are essential organic substances in the metabolic processes of living things, which aid the assimilation of nutrients within the human body. Because vitamins participate in multiple functions (antioxidants, immune function, endothelial homeostasis, bone metabolism, connective tissue stability, central nervous system modulation, etc), of the organism and constitute one of the main pillars for its growth, certain vitamin deficits have been associated with neurological, hematological, musculoskeletal, endocrinological, immunological and cardiovascular defects, for these reason, vitamin deficits require an effective and comprehensive approach because they are complex entities from clinical, ethical and humanistic perspectives, and supplementations is only recommended in conditions of nutritional supplementation deficits ${ }^{1-4}$.

Although the consumption of vitamin supplements increased over the past decades due to their possible health benefits 5 , approximately two billion people have low levels of the main vitamins and minerals ${ }^{6}$, of which an estimated 30-50\% have a vitamin D deficit ${ }^{7}$, and approximately 8.5 to $51 \%$ are deficient in vitamin B12. Certain circumstances or special procedures are known to be associated with decreased vitamin levels in the body; for example, deficits of vitamins A, B1, B6, B9, B12, D and E have been documented in patients after bariatric surgery ${ }^{8,9}$.

Consequently, vitamin supplement consumption has increased, with an estimated 49 to $52 \%$ of United States citizen adults using vitamin supplements regularly 5 , figures that may reach up to $63 \%$ among peopleaged more than 60 years ${ }^{10}$ and up to $70 \%$ among those older than 70 years ${ }^{11}$. Vitamin consumption is more frequent among women, patients with low body mass index, non-smokers and those with high levels of education, socioeconomic status and physical activity ${ }^{12}$. Most vitamin supplementation is accompanied by mineral supplementation, including calcium; however, according to some studies, most people consume only $30 \%$ of the daily recommended calcium intake, a mineral for which deficiencies are associated with osteopenia and osteoporosis ${ }^{13}$.

Scarce information exists regarding the frequency of vitamin supplement use in Colombia; thus, understanding their use might establish a baseline upon which strategies could be proposed to harmonizetheiruse, e.g., increasing their dispensation where needs are identified or decreasing their dispensation based on inappropriate use. Based on this hypothesis, we sought to determine prescription patterns of vitamins in a group of patients affiliated to the Health System of Colombia (SGSSS) in the year 2016.

\section{Materials and methods}

A cross-sectional study on vitamin prescription patterns was conducted in a population of approximately 3.5 million people affiliated with the SGSSS-participating program of two insurers, called Health Promoting Companies (EPS for its initials in Spanish). The characteristics of patients treated with vitamins were analyzed in the period between July 1 and September 30, 2016 in all Colombian cities where they were prescribed.

Data was taken from all individuals of any ages and sex who used this group of medications, attended 
an outpatient clinic visit and whose treatment was maintained uninterruptedly for at least three months were included (sample calculation was not performed). This requirement was intended to ensure that patients were on an approximately stable treatment, reflecting medication tolerance and adherence. Exclusion criteria were not considered.

Based on the information concerning the consumption of medications of the affiliated population, obtained systematically by the dispensing company Audifarma SA. Each dispensing of the medication is registered together with sociodemographic and diagnostic data, a database was designed to collect the following groups of patient variables: sociodemographic variables were evaluated (sex, age and city), Pharmacological variables (Prescribed active ingredient, vitamin or micronutrient supplement) and its formulation, dosage and dosage interval. The daily defined dose (DDD) and the DDD per thousand inhabitants per day were used as the measures of use. Comedications were also evaluated and were accepted as a proxy indicator of chronic disease, considering the following associations: a) antidiabetics and insulins/ diabetes mellitus; B) analgesics (nonsteroidal anti-inflammatory drugs, acetaminophen, corticosteroids)/chronic pain; C) antirheumatics/ rheumatoid arthritis; D) antidepressants/depressive disorder; E) lipid-lowering agents/dyslipidemia; F) thyroid hormone preparations/hypothyroidism; G) nitrovasodilators/ischemic heart disease; and $\mathrm{H}$ ) antihypertensives and diuretics/arterial hypertension.

The protocol was endorsed by the Bioethics Committee of the Technological University of Pereira under the category of "research without risk", and the principles established by the Declaration of Helsinki were respected.

\section{Statistical analysis}

The statistical package SPSS Statistics, version 23.0 (IBM, USA) for Windows was used for the data analysis. Descriptive statistics were used, including measures of central tendency, position and dispersion depending on the normal behavior of the continuous variables (Shapiro-Wilk or KolmogorovSmirnov test) and frequencies and proportions for categorical variables. Student t-tests or ANOVA were used to compare quantitative variables and $X^{2}$ was used for categorical variables. Logistic regression models were used, as dependent variables with use of vitamins as monotherapy or in combined therapy and use or no use of comedication, whereas covariables were those factors demonstrating significant associations in the bivariate analyses. A p-value <0.05 was determined as the level of statistical significance.

\section{Results}

A total of 9998 patients affiliated with these EPS were prescribed some type of vitamin supplement. A female predominance was observed, totaling 8341 women (83.4\%). Regarding the age distribution, $2.2 \%$ were younger than 18 years, $19.2 \%$ were aged between 18 and 34 years, 33.8\% were aged between 35 and 64 years and $34.9 \%$ were older than 65 years. No age data was available regarding the remaining 9.9\%. Figure 1 shows the population distribution by age and sex. The mean age was $57.7 \pm 18.7$ years (range 0-100 years) with a significant difference between men and women $(59.4 \pm 20.2$ years versus $57.4 \pm 18.4$ years respectively; $p<0.001$ ) (Figure 1 ).

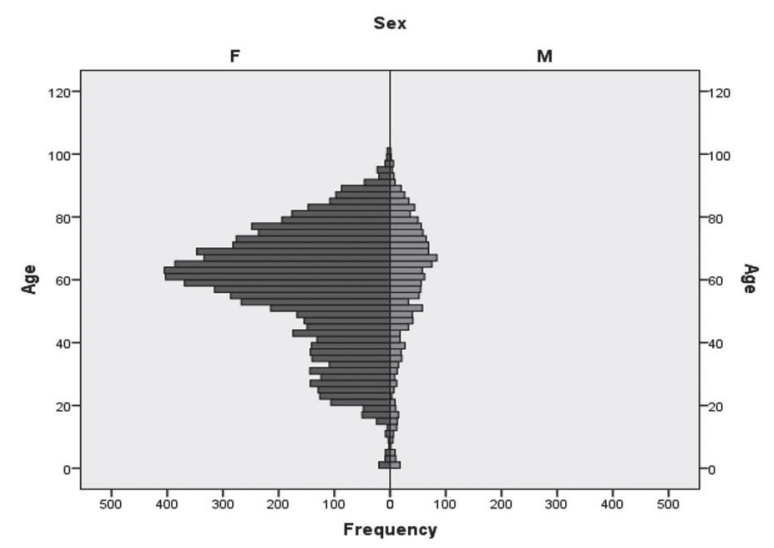

Figure 1. Distribution of the 9998 patients with vitamin prescription included in the study according to age and sex, Colombia, 2016 Source: authors.

The most commonly formulated vitamins and supplements were vitamin D (58.0\%), calcium (55.0\%), folic acid (25.0\%), iron (13.0\%) and thiamine (8.0\%). Table 1 summarizes the prescription patterns of the major vitamins dispensed to outpatients, including their frequency, average dose and DDD. Table 2 summarizes the distribution of vitamins for the age groups and the most frequently prescribed types in the sample evaluated (Table 1 and 2). 
Table 1. Patterns of prescription of vitamins and supplements in 9998 patients affiliated to the Health System of Colombia, 2016.

\begin{tabular}{|c|c|c|c|c|c|c|c|c|c|}
\hline \multirow[t]{2}{*}{ Medication } & \multirow{2}{*}{$\begin{array}{l}\text { Prescription } \\
\text { \# Patients }\end{array}$} & \multicolumn{4}{|c|}{ Prescribed dose } & \multirow[t]{2}{*}{ nDDD } & \multirow{2}{*}{$\begin{array}{l}\text { DDD X } 1000 \\
\text { inhabitants / } \\
\text { day }\end{array}$} & \multirow{2}{*}{$\begin{array}{l}\text { H: M } \\
\text { relation }\end{array}$} & \multirow{2}{*}{$\begin{array}{l}\text { Mean age } \\
\text { (SD) }\end{array}$} \\
\hline & & $\%$ & Mean & $\begin{array}{l}\text { Standard } \\
\text { deviation }\end{array}$ & Mode & & & & \\
\hline Vitamin D (IU / day) & 5847 & 58.5 & 388.5 & 657.3 & 200 & 0.49 & 0.95 & $1: 10$ & 62.6 \\
\hline Calcium (mg / day) & 5505 & 55.1 & 706.7 & 438.7 & 600 & & & $1: 8$ & 62.8 \\
\hline Folic Acid (mg / day) & 2523 & 25.2 & 1.2 & 0.9 & 1 & 2.90 & 2.45 & $1: 5$ & 19.8 \\
\hline Iron (mg / day) & 1330 & 13.3 & 290.8 & 77.7 & 300 & 1.45 & 0.65 & $1: 9$ & 40.9 \\
\hline Thiamine (mg / day) & 828 & 8.3 & 317.5 & 92.9 & 300 & 6.35 & 0.11 & $1: 2$ & 66.2 \\
\hline Ascorbic acid (mg / day) & 667 & 6.7 & 645.9 & 352.3 & 500 & 3.23 & 0.72 & $1: 2$ & 56.0 \\
\hline Cyanocobalamin (mg / day) & 423 & 4.2 & 0.1 & 0.1 & 0,033 & 0.07 & 0.01 & $1: 2$ & 61.4 \\
\hline Vitamin A (IU / day) & 152 & 1.5 & 59367.2 & 22643.7 & 50000 & 1.19 & 0.06 & $1: 1$ & 40.6 \\
\hline Vitamin E (mg / day) & 34 & 0.3 & 645.1 & 265.1 & 800 & 3.23 & 0.04 & $1: 0.7$ & 40.5 \\
\hline Vitamin K (mg / day ) & 3 & 0.03 & 1.8 & 1.9 & & 0.09 & 0.00 & & 6.6 \\
\hline
\end{tabular}

Relationship between the prescribed daily dose and the defined daily dose

Source: authors.

Table 2. Frequency of use and average dose of vitamins and supplements in patients affiliated with the health system of Colombia, 2016.

\begin{tabular}{|c|c|c|c|c|c|c|c|c|}
\hline & $<18$ years & & 18 to 44 years & & 45 to 65 years & & $>65$ years & \\
\hline Medication & $\begin{array}{c}N=218 \\
(2.2 \%)\end{array}$ & $\begin{array}{l}\text { Mean } \\
\text { dose }\end{array}$ & $\begin{array}{c}N=1932 \\
(19.3 \%)\end{array}$ & $\begin{array}{c}\text { Mean } \\
\text { dose }\end{array}$ & $\begin{array}{c}N=3398 \\
(3.4 \%)\end{array}$ & $\begin{array}{l}\text { Mean } \\
\text { dose }\end{array}$ & $\begin{array}{c}N=3469 \\
(34.7 \%)\end{array}$ & $\begin{array}{r}\text { Mean } \\
\text { dose }\end{array}$ \\
\hline Vitamin D & $49(22 \%)$ & 964.2 & $531(27 \%)$ & 451.2 & $2290(67 \%)$ & 412.3 & $2332(67 \%)$ & 356.3 \\
\hline Calcium & $37(17 \%)$ & 735.0 & $495(26 \%)$ & 879.7 & $2144(63 \%)$ & 719.1 & $2206(15 \%)$ & 661.9 \\
\hline Folic acid & $52(24 \%)$ & 1.0 & $1073(56 \%)$ & 1.1 & $720(21 \%)$ & 1.1 & $512(15 \%)$ & 1.3 \\
\hline Iron & $41(19 \%)$ & 267.9 & $822(63 \%)$ & 294.5 & $149(4 \%)$ & 275.0 & $230(7 \%)$ & 288.8 \\
\hline Thiamine & $2(1 \%)$ & 550.0 & $63(3 \%)$ & 295.2 & $279(8 \%)$ & 324.5 & $430(12 \%)$ & 318.4 \\
\hline Ascorbic acid & $64(29 \%)$ & 370.5 & $93(5 \%)$ & 647.2 & $211(6 \%)$ & 660.2 & $240(7 \%)$ & 690.2 \\
\hline Cyanocobalamin & $1(0 \%)$ & 0.2 & $57(3 \%)$ & 0.1 & $179(5 \%)$ & 0.1 & $146(4 \%)$ & 0.1 \\
\hline
\end{tabular}

Source: authors.

\section{Monotherapy and polytherapy}

From all the patients included in the study, 3919 (39.2\%) were prescribed only one vitamin or nutritional supplement, and the remainder were prescribed two or more active nutrients. The most frequent combinations were calcium and vitamin $D$ ( $n=5505,55.1 \%)$; iron and folic acid $(n=848,8.4 \%)$; vitamin $D$ and folic acid ( $n=554,5.5 \%)$; calcium and folic acid $(n=552,5.5 \%)$; and thiamine and vitamin $D$ $(n=185,1.8 \%)$.

\section{Comedications}

Of the total number of patients, 7727 (77.3\%) received concomitant treatment with one or more of the following groups of drugs: antihypertensives, analgesics and antipyretics, statins, nitrates, thyroid hormones and corticosteroids. Their frequencies and other medications were evaluated (Table 3).

Binary logistic regression analysis of comedication revealed that the following variables were 
significantly associated with a lower probability of receiving any other drug: age between 14 and 18 years (OR: $0.23,95 \% \mathrm{Cl}: 0.15-0.33$ ), age between 18 and 45 years (OR: $0.37,95 \% \mathrm{Cl}: 0.30-0.46$ ), iron supplementation (OR: $0.59,95 \% \mathrm{Cl}: 0.50-0.69$ ) and being female (OR: $0.75 ; 95 \% \mathrm{Cl}$ : 0.64-0.86). Age greater than 65 years (OR: 1.24; 95\% Cl: 1.02-1.51), formulations with folic acid (OR: 3.10; 95\% Cl: 2.69-
3.59); thiamine (OR: $2.75 ; 95 \% \mathrm{Cl}: 2.15-3.50$ ), calcium + vitamin D (OR: $1.61,95 \% \mathrm{Cl}: 1.42-1.82)$ or treatment in one of the cities of Manizales (OR: $1.76,95 \% \mathrm{Cl}$ : 1.38-2.25), Bucaramanga (OR: 1.71, 95\% Cl: 1.28-2.27), Bogota (OR: 1.71; 95\% Cl: 50-1.95), Barranquilla (OR: 1.52, 95\% Cl: 1.22-1.90) or Cartagena (OR: 1.47, 95\% Cl: 1.16-1.85) were associated with a greater probability of receiving some type of comedication.

Table 3. Comparison of some demographic variables and prescription indicators of vitamins and supplements in different colombian cities, 2016.

\begin{tabular}{|c|c|c|c|c|c|c|}
\hline \multirow{2}{*}{ Variables } & Bogotá & Barranquilla & Manizales & Cartagena & Bucaramanga & Colombia \\
\hline & $n=6140$ & $n=645$ & $n=559$ & $n=523$ & $n=466$ & $n=9998$ \\
\hline Women (\%) & 85.4 & 72.2 & 83.7 & 80.1 & 78.1 & 83.4 \\
\hline Monotherapy (\%) & 86.5 & 65.7 & 75.1 & 60.6 & 81.3 & 80.3 \\
\hline Comedication (\%) & 87.8 & 77.5 & 80.5 & 71.3 & 82.6 & 77.3 \\
\hline \multicolumn{7}{|c|}{ Prescription (\%) } \\
\hline Vitamin D & 67.6 & 30.7 & 68.5 & 17.4 & 38.4 & 58.5 \\
\hline Calcium & 65.7 & 30.2 & 66.0 & 17.2 & 37.3 & 55.1 \\
\hline Folic acid & 20.7 & 37.8 & 28.4 & 52.6 & 11.4 & 25.2 \\
\hline Iron & 6.7 & 24.0 & 15.0 & 47.2 & 9.2 & 13.3 \\
\hline Thiamine & 5.1 & 18.6 & 5.2 & 4.4 & 45.5 & 8.3 \\
\hline Ascorbic acid & 5.5 & 16.3 & 1.3 & 14.7 & 9.4 & 6.7 \\
\hline Cyanocobalamin & 3.2 & 14.7 & 6.1 & 5.4 & 2.3 & 4.2 \\
\hline Vitamin A & 1.8 & 1.4 & 0.5 & 0.0 & 0.9 & 1.5 \\
\hline Vitamin E & 0.4 & 0.2 & 0.0 & 0.2 & 0.2 & 0.3 \\
\hline Vitamin K & 0.0 & 0.0 & 0.0 & 0.0 & 0.0 & 0.0 \\
\hline \multicolumn{7}{|c|}{ Comedication ( $\%)$} \\
\hline Antihypertensives & 42.9 & 42.0 & 44.9 & 41.10 & 56.4 & 41.7 \\
\hline Statins & 27.3 & 24.7 & 39.0 & 25.6 & 39.7 & 27.5 \\
\hline Anti-ischemic & 24.7 & 21.9 & 24.3 & 22.6 & 31.5 & 24.3 \\
\hline Thyroid Hormones & 24.7 & 21.9 & 24.3 & 8.8 & 22.3 & 23.4 \\
\hline DMARDs & 15.1 & 11.8 & 20.8 & 6.1 & 12.0 & 13.5 \\
\hline Antidepressants & 11.7 & 14.1 & 22.4 & 7.5 & 17.8 & 12.9 \\
\hline Corticosteroids & 12.9 & 17.4 & 21.6 & 6.9 & 10.3 & 12.8 \\
\hline Antidiabetics & 10.5 & 10.1 & 9.5 & 12.4 & 17.8 & 10.6 \\
\hline NSAIDs & 9.1 & 14.7 & 6.3 & 4.8 & 17.8 & 9.5 \\
\hline
\end{tabular}

NSAIDs: non-steroidal anti-inflammatory drugs, DMARDs: Disease-Modifying Antirheumatic Drugs

Source: authors. 


\section{Comparison by city}

We identified 18 cities in the country in which patients were prescribed some types of vitamins and supplements. Table 3 shows a comparison of some usage indicators for the five cities with the highest number of patients, which represent $83.3 \%$ of the usage by all the evaluated populations, and the usage indicators of the country as a whole (Table 3 ).

\section{Discussion}

This study describes the prescription patterns of vitamins and other supplements among patients affiliated in two different EPS of the Colombian Health System. Vitamin and micronutrient usage habits in the population with supplement prescription, such as those for vitamin D, calcium, folic acid and iron, among others, were identified. These reallife utilization results may allow optimized and methodological prescribing and improve the quality of care, cost and safety of patient therapy.

A predominance of vitamin and supplement use among women was observed (5:1 ratio). Some studies of over-the-counter use in Europe and Asia describe a similar trend; for example, in Europe in the study by Skeie et al in 2009, they found up to 10 times more supplements use in women, especially between the ages of 35 and 74, and in the United States in the study carried out by Kantor et al in 2016 the relationship is slightly higher in women, although the way of evaluating the use of supplements was different. However, in our study vitamins and supplements are drugs prescribed through a health system $^{14-17}$.

Adults older than 65 years received more vitamin prescriptions. According to a study conducted in the US in $2016,72 \%$ of older adults had consumed vitamins in the prior month, showing that consumption increases with advanced age ${ }^{16,17}$. Unlike the study by Piccano et al. in the US, which showed that children aged 4 to 8 years were the main consumers of vitamins, we found in this study that vitamins were prescribed to only $2.2 \%$ of those younger than 18 years ${ }^{18}$.

On average, the doses that patients were receiving were higher than those recommended by the WHO for each vitamin or supplement except for calcium and vitamin $D^{19}$, which were generally less than $60 \%$ of the doses established for each of these nutrients.
The prescription of a joint formulation of calcium and vitamin $\mathrm{D}$ was more frequent than that of both compounds separately, mainly in the population older than 45 years, which is likely related to the indication for improving bone mineral density in patients at risk of osteoporosis, notably because such combination has shown better results, with a $12 \%$ greater reduction in fracture risk compared to the administration of calcium alone ${ }^{4,20}$.

The use of folic acid was concentrated in the group of women aged between 18 and 45 years; thus, it is hypothesized that its use in a population of childbearing age might have been indicated for the prevention of fetal neural tube alterations ${ }^{21}$, pattern of use similar to that reported for example by Wong et al in the United States in 2019, where women of reproductive age consume more folic acid supplement, especially between 18-24 years and mainly during pregnancy and the preconception period $^{22}$. However, a study conducted in 2013 in major cities (15 different institutions) in Colombia found inadequate folic acid usage in a population of pregnant patients due to insufficient consumption ${ }^{21}$. Folic acid supplementation is a safe strategy recommended by international organizations for this indication ${ }^{23,24}$ and for the management of anemias due to the deficiency of this micronutrient in other population groups such as those older than 45 years, in whom its use was also frequent ${ }^{25,26}$.

Similar to folic acid, a significant number of patients mainly in the fertile age group (18-45 years) were identified as receiving ferrous sulfate. A study indicated that in 2011, approximately 528 million women of reproductive age had anemia, with iron deficiency the cause in $50 \%$ of the cases ${ }^{27}$; therefore, its use in this group should prevent this type of anemia during gestation ${ }^{23}$.

Vitamin C was prescribed more commonly in children aged less than 18 years. Although it has been used for years for the prevention of the common cold, no evidence supports that expected effect in the general population ${ }^{28,29}$. Thus, inquiring about the indications of its use is pertinent based on its poor therapeutic benefit ${ }^{4}$.

Most medications were prescribed in patients with pathologies of cardiovascular origin, for which drug-vitamin interactions are not clinically relevant; however, such interactions require consideration regarding the group of patients being treated as 
does the sum of medications that may lead to inappropriate polypharmacy and reduced adherence to treatment ${ }^{30}$.

On a global level, the consumption of multivitamins has grown more than that of individual vitamin or mineral formulations, which was also evident in this study, notwithstanding the fact that over-thecounter products were not studied ${ }^{16,31}$. Typically, multivitamin use is associated with the intention of improving or maintaining health conditions without prior consultation with a health professional; however, the fact that these are not harmless products warrants consideration ${ }^{31}$.

The differences found in the patterns of use of vitamins in the Colombian cities included in the study as related to the frequency of use were expected because discrepancies in care, medical education and particularly prescription habits are persistent findings in drug-epidemiological studies. These variations, which are important because of their medical, social and economic implications, are related to patient characteristics (age, sex and comorbidity) and to professional practice styles that originate from personal factors and the academic training of physicians ${ }^{32,33}$.

This study has limitations regarding the interpretation of some results, such as the inclusion of patients from only two EPSs, which excludes the possibilities of extrapolation to subsidized populations and assessments such as the use of vitamin supplements without medical prescription or use in over-the-counter supplement, along with the possible indications or diagnoses associated with such use. However, important study strengths exist such as the broad sample used, the reliability of the data regarding the included dispensations and, considering that vitamin and supplement use in Colombia has not been described previously, its innovation.

\section{Conclusions}

The aforementioned results indicate that the vitamins and supplements most widely used in daily medical practice are vitamin $\mathrm{D}$ and calcium, generally combined, followed by folic acid, iron and thiamine in women older than 35 years, and in general in higher doses than recommended; moreover, vitamin and supplement users are frequently receiving medications for various comorbidities, particularly arterial hypertension, arthropathies and dyslipidemia. The findings of this pharmacoepidemiological study provide decision makers and prescribing physicians with a useful tool because they offer them an understanding of and evidence for their real-world uses.

\section{Acknowledgements}

To Soffy López by her support to obtain the database.

\section{Conflict of interest}

This research had no sources of funding. The authors declare that they have no conflict of interest.

\section{Bibliographic references}

1. Brito A, Hertrampf E, Olivares M, Gaitan D, Sanchez H, Allen LH, et al. Folate, vitamin B12 and human health. Rev Med Chil. 2012;140(11):1464-75. DOI:10.4067/S0034-98872012001100014

2. Rosen CJ, Adams JS, Bikle DD, Black DM, Demay MB, Manson JE, et al. The nonskeletal effects of vitamin D: an Endocrine Society scientific statement. Endocr Rev. 2012;33(3):456-92. DOI:10.1210/er.2012-1000

3. Ramírez-Vélez R, Correa-Bautista JE, Martínez-Torres J, MenesesEchávez JF, Lobelo F. Vitamin B12 concentrations in pregnant Colombian women: analysis of nationwide data 2010. BMC Pregnancy and Childbirth. 2016;16(1):16-26. DOI:10.1186/ s12884-016-0820-4

4. Giraldo HJU, Betancur MAQ, García LAR, Merchán CAG, Grisales JCB. Controversias sobre el uso de micronutrientes. Rev Méd Risaralda. 2009;15(2):43-52

5. Sedjo RL, Neuhouser ML, Rock CL. Dietary Supplements and Cancer Risk: Epidemiologic Research and Recommendations. Preventive Nutrition: Springer; 2015: 183-214.

6. Tulchinsky TH. Micronutrient deficiency conditions: global health issues. Public Health Rev. 2010;32(1):243

7. Nakashima A, Yokoyama K, Yokoo T, Urashima M. Role of vitamin $\mathrm{D}$ in diabetes mellitus and chronic kidney disease. World J Diabetes. 2016;7(5):89-100. DOI:10.4239/wjd.v7.i5.89

8. Dudorova EY, Damulin IV, Khatkov IE. Neurological complications due to vitamin deficiencies after bariatric surgery. Ter Arkh. 2015;87(12):117-21

9. Folope V, Coeffier M, Dechelotte P. Nutritional deficiencies associated with bariatric surgery. Gastroenterol Clin Biol. 2007;31(4):369-77

10. Ulrich C, Potter J, Ulrich N. Folate supplementation: Too much of a good thing? Cancer Epidemiol Biomarkers Prev. 2006;15(2):189-93.

11. Bailey RL, Gahche JJ, Lentino CV, Dwyer JT, Engel JS, Thomas PR, et al. Dietary supplement use in the United States, 2003-2006. J Nutr. 2011;141(2):261-6.

12. Foote JA, Murphy SP, Wilkens LR, Hankin JH, Henderson BE, Kolonel LN. Factors Associated with Dietary Supplement Use among Healthy Adults of Five Ethnicities: The Multiethnic Cohort Study. Am J Epidemiol. 2003;157(10):888-97.

13. O'Keefe JH, Bergman N, Carrera-Bastos P, Fontes-Villalba M, DiNicolantonio JJ, Cordain L. Nutritional strategies for skeletal and cardiovascular health: hard bones, soft arteries, rather than vice versa. Open Heart. 2016 Mar 22;3(1):e000325. PubMed PMID: 27042317.

14. Skeie G, Braaten T, Hjartåker A, Lentjes M, Amiano P, Jakszyn P, et al. Use of dietary supplements in the European Prospective Investigation into Cancer and Nutrition calibration study. Eur J Clin Nutr. 2009;63(4):226-38.

15. Park SY, Kim YJ, Lee SY, Lee JG, Hwang HR, Jeong DW, et al. 
Vitamin-Mineral Supplement Use Patterns in Elderly Koreans: Data from the 2007-2008 Korean National Health and Nutrition Examination Survey. Korean J Fam Med. 2016;37(2):123-9.

16. Kantor ED, Rehm CD, Du M, White E, Giovannucci EL. Trends in dietary supplement use among US adults from 1999-2012. JAMA. 2016;316(14):1464-74

17. Bailey RL, Gahche JJ, Miller PE, Thomas PR, Dwyer JT. Why US adults use dietary supplements. JAMA Intern Med. 2013;173(5):355-61.

18. Picciano MF, Dwyer JT, Radimer KL, Wilson DH, Fisher KD, Thomas PR, et al. Dietary supplement use among infants, children, and adolescents in the United States, 1999-2002. Arch Pediatr Adolesc Med. 2007;161(10):978-85.

19. World Health Organization. Guidelines for ATC classification and DDD assignment [Internet] Geneve, 2017. [cited June/2017] Available: https://www.whocc.no/atc ddd index/.

20. Loza Santamaría E. Suplementos de calcio y vitamina D ipara todos?: Contras [IV Simposio de Patologías Metabólicas Óseas]. Reumatol Clín . 2011;7(2):40-5.

21. Holguín-Hernández E, Orozco-Díaz JG. Administración de ácido fólico y otros micronutrientes en mujeres embarazadas de Colombia. Rev Panam Salud Pública. 2013;34(2):99-106.

22. Wong EC, Rose CE, Flores AL, Yeung LF. Trends in Multivitamin Use Among Women of Reproductive Age: United States, 20062016. J Womens Health (Larchmt). 2019;28(1):37-45

23. Ministerio de Salud y Protección Social. Guía de Práctica Clínica, detección temprana y tratamiento del embarazo, parto o puerperio [Internet]. Bogotá, 2013. [citado en Junio/2017]. Disponible en: https://www.minsalud.gov.co/sites/rid/Lists/ BibliotecaDigital/RIDE/INEC/IETS/Gu\% C3\%ADa.completa. Embarazo.Parto.2013.pdf.
24. OrganizaciónMundialdelaSalud.Directriz:Administracióndiaria de suplementos de hierro y ácido fólico en el embarazo [Internet]. Ginebra, 2014. [citado en June/2017] Disponible en: http://apps. who.int/iris/bitstream/10665/124650/1/9789243501994 spa.pdf.

25. Castellanos-Sinco HB, Ramos-Peñafiel CO, Santoyo-Sánchez A Collazo-Jaloma J, Martínez-Murillo C, Montaño-Figueroa E, et al. Megaloblastic anaemia: Folic acid and vitamin B12 metabolism. Rev Méd Hosp Gen Méx. 2015;78(3):135-43.

26. Green R, Datta Mitra A. Megaloblastic Anemias: Nutritional and Other Causes. Med Clin North Am. 2017;101(2):297-317.

27. Percy L, Mansour D, Fraser I. Iron deficiency and iron deficiency anaemia in women. Best Pract Res Clin Obstet Gynaecol. 2017; $40: 55-67$.

28. Hemilä H, Chalker E. Vitamin C for preventing and treating the common cold. Cochrane Database Syst Rev. 2013 Jan 31;(1):CD000980. PubMed PMID: 23440782

29. Martini L, Pecoraro L, Salvottini C, Piacentini G, Atkinson R, Pietrobelli A. Appropriate and inappropriate vitamin supplementation in children. J Nutr Sci. 2020;9:e20.

30. Maher RL, Hanlon JT, Hajjar ER. Clinical Consequences of Polypharmacy in Elderly. Expert Opin Drug Saf. 2014;13(1):57-65.

31. Valavanidis A. Dietary supplements: Beneficial to human health or just peace of mind? A critical review on the issue of benefit/ risk of dietary supplements. Pharmakeftiki. 2016;28(2):60-83.

32. Machado-Alba J, Valencia-Marulanda J, Jiménez-Canizales C, Salazar V, Romero D. Patrones de prescripción de hormonas tiroideas en una población colombiana. Rev Panam Salud Pública. 2014;36(2):80-6.

33. Machado Alba JE, Moncada Escobar JC, Mesa Escobar G. Patrones de prescripción de antidiabéticos en un grupo de pacientes colombianos. Rev Panam Salud Pública. 2007;22(2):124-31 